\title{
BATASAN KEBEBASAN BERPENDAPAT MELALUI MEDIA ELEKTRONIK DALAM PERSPEKTIF HAM DIKAITKAN DENGAN TINDAK PIDANA MENURUT UU ITE
}

\author{
Fadilah Raskasih \\ Universitas Riau, Indonesia, fadilahraskasih@gmail.com
}

\begin{abstract}
This study aims to determine the limitations of freedom of expression through electronic media viewed from the perspective of Human Rights associated with criminal acts, and to recognize the ideal arrangement of freedom of expression limitations through electronic media. This study uses a doctrinal type of research. The results of the study show that the Human Rights and the prevailing laws and regulations relating to freedom of expression, must be balanced. So the current regulations regarding the freedom of expression are deemed necessary. However, it requires a more detailed explanation concerning several categories that are considered as violations of Human Rights against others.
\end{abstract}

Key words: Freedom of Expression, Electronic Media, Human Rights, Crime.

\begin{abstract}
Abstrak
Penelitian ini bertujuan untuk mengetahui batasan kebebasan berpendapat melalui media elektronik dilihat dari perspektif Hak Asasi Manusia dikaitkan dengan tindak pidana serta untuk mengetahui pengaturan yang ideal tentang batasan kebebasan berpendapat melalui media elektronik dilihat dari perspektif Hak Asasi Manusia dikaitkan dengan tindak pidana. Penelitian ini menggunakan jenis penelitian doktrinal. Hasil penelitian menunjukkan bahwa antara Hak Asasi Manusia (HAM) dan peraturan perundang - undangan yang berlaku terkait dengan kebebasan berpendapat harus seimbang, sehingga peraturan terkait kebebasan berpendapat saat ini dianggap perlu. Hanya saja dibutuhkan penjelasan lebih rinci terkait dengan beberapa kategori yang dianggap sebagai pelanggaran HAM terhadap orang lain.
\end{abstract}

Kata Kunci : Kebebasan Berpendapat, Media Elektronik, Hak Asasi Manusia (HAM), Tindak Pidana. 


\section{Pendahuluan}

Hak Asasi Manusia (HAM) adalah anugerah yang diberikan oleh Tuhan YME kepada manusia, yang biasa juga disebut dengan hak kodratiah yang melekat pada diri seseorang sebagai sebuah karunia pemberian Tuhan kepada insan manusia dalam menopang dan mempertahankan hidup dan prikehidupannya di muka bumi. Jika HAM merupakan hak yang diperoleh setiap manusia sebagai konsekuensi ia ditakdirkan lahir sebagai manusia, maka lain halnya dengan hak dasar, sebagai suatu hak yang diperoleh setiap manusia sebagai konsekuensi ia menjadi warga Negara dari suatu Negara. dengan kata lain, HAM berasal dari Tuhan, sedangkan hak dasar berasal dari Negara atau pemerintah. ${ }^{1}$ Akan tetapi, ada hal yang perlu diingat bahwa dalam hal pemenuhan hak, kita hidup tidak sendiri dan kita hidup bersosialisasi dengan orang lain oleh sebab itu, dalam pemenuhan hak kita tidak boleh semena-semena mengingat bahwa orang lain juga memiliki hak yang sama dengan kita. Dengan kata lain bahwa istilah penyalahgunaan hak merupakan suatu contradictio in terminis atau setidaknya suatu istilah yang mengandung kerancuan berpikir(dubious). ${ }^{2}$

Pemaknaan tentang hak yang menjadi landasan dari pembahasan tentang HAM mempunyai makna

\footnotetext{
${ }^{1}$ Nurul Qamar, 2016, Hak Asasi Manusia dalam Negara Hukum Demokrasi, Jakarta: Sinar Grafika, h. 16-17.

${ }^{2}$ Ibid.
}

yang luas yang bernuansa moral sekaligus politik. Konsepsi tentang rights (hak dasar) di dalam Bahasa Inggris tidak dapat diterjemahkan dengan makna tunggal ke dalam bahasa Indonesia. Di dalam makna rights terkandung beragam makna seperti privilege (kehormatan), immunity (kekebalan), claims (klaim), entitlement (sesuatu yang dimiliki), power (kekuasaan), dan expectation (sesuatu yang menjadi harapan). ${ }^{3}$

Banyak pakar yang telah mendefiniskan tentang HAM. Frans Magnis Suseno mendefinisikan HAM sebagai hak dasar atau hak yang bersifat mutlak dan merupakan anugerah dari Yang Maha Kuasa, yaitu sejak manusia ada atau dilahirkan. HAM "ada" bukan karena diberikan masyarakat dan kebaikan dari Negara, melainkan berdasarkan martabat seseorang sebagai manusia. ${ }^{4}$ Tekait dengan kebebasan berpendapat, Jimly Asshiddiqie mengemukakan bahwa:

"Materi HAM yang telah diadopsi ke dalam rumusan UUD NKRI Tahun 1945 mencakup 27 materi dan beberapa diantaranya terdapat pengaturan terkait kebebasan dalam mengemukakan pendapat dan kebebasan memanfaatkan berbagai

\footnotetext{
${ }^{3}$ Ani W. Soetjipto, 2015, HAM dan Politik Internasional: Sebuah Pengantar, Jakarta: Yayasan Putra Obor Indonesia, h. 15.

4 Frans Magnis Suseno dalam Emilda Firdaus, 2015, Perlindungan Perempuan Korban KDRT Menurut HAM di Indonesia, Yogyakarta: Genta Publishing, h. 1-2.
} 
media untuk mengumpulkan dan menyampaikan berbagai informasi yang bertujuan untuk pengembangan diri.",5

Hal tersebut juga telah disebutkan di dalam UU No. 39 Tahun 1999 Tentang HAM Pasal 13 dan 25, sehingga dapat dikatakan bahwa kebebasan berpendapat, berkomunikasi, memperoleh dan menyampaikan informasi melalui berbagai media adalah sebuah hal yang sah saja untuk dilakukan dan merupakan sebuah Hak yang dimiliki oleh setiap manusia terkhusus bagi masyarakat Indonesia.

Di era globalisasi ini, isu isu tentang HAM tentu sudah menjadi hal yang tidak asing lagi untuk kita dengar. Banyak sekali kasus-kasus tindak pidana yang terjadi terkait dengan HAM. Secara umum, pendapat sendiri dapat diartikan sebagai sebuah gagasan atau ide. Gagasan atau ide di dalam Kamus Besar Bahasa Indonesia (KBBI) adalah rancangan yang tersusun di pikiran, artinya sama dengan cita - cita. Gagasan akan menyebabkan timbulnya konsep, yang merupakan dasar bagi segala macam pengetahuan. Selama gagasan belum dituangkan menjadi suatu konsep dengan tulisan maupun gambar yang nyata, maka gagasan masih berada di dalam pikiran. ${ }^{6}$ Saat ini dengan maraknya kemajuan ilmu

\footnotetext{
${ }^{5}$ Jimly Asshidiqie dalam Nurul Qamar, $O p$. Cit., h. 102.

6 https://id.m.wikipedia.org/wiki/gagasan Diakses Senin Tanggal 22 Mei 2017
}

pengetahuan dan teknologi tentu saja membawa pengaruh yang besar terhadap kehidupan dan kebudayaan yang ada di masyarakat untuk itu di dalam kehidupan bernegara tentu saja kebebasan berpendapat dijamin dan dibatasi secara konstitusional.

$$
\text { Perkembangan teknologi }
$$
merupakan salah satu faktor yang dapat menimbulkan kejahatan, sedangkan kejahatan itu sendiri telah ada dan muncul sejak permulaan zaman, sekarang dan yang akan datang ${ }^{7}$ karena pada dasarnya kemajuan dan perkembangan berdampak positif dan negatif. Seperti kita ketahui bersama melalui kemajuan pengetahuan dan teknologi sekarang ini masyarakat menjadi semakin kreatif dalam menyampaikan pendapat dan menyalurkan aspirasinya. Berbagai media khususnya media elektronik menjadi suatu hal yang diminati.

Kehadiran media elektronik sebagai bagian dari perkembangan teknologi telah membuka cakrawala baru dalam kehidupan manusia. Media eletronik membuat sebuah ruang informasi dan komunikasi yang menjanjikan menembus batasbatas antar negara. Media elektronik kemudian membawa kemajuan dengan membentuk dunia baru yang dianggap sebagai dunia tanpa batas.

Hal yang kemudian menjadi masalah adalah perbedaan persepsi tentang hak menyampaikan pendapat khususnya melalui media elektronik menjadi pemicu lahirnya konflik -

\footnotetext{
${ }^{7}$ www.elib.unikom.ac.id/files/disk1 Diakses Senin Tanggal 22 Mei 2017
} 
konflik di dalam masyarakat. Merujuk pada beberapa kasus yang pernah terjadi terkait dengan menyampaikan pendapat melalui media elektronik terkadang permasalahan hanya dipicu oleh masalah sepele. Hanya karena menyampaikan kritik terkadang seseorang dapat dilaporkan dan bahkan dapat ditahan, atau bisa jadi karena alasan HAM seseorang yang menghina atau melecehkan orang lain tidak dapat dituntut dan bahkan dibebaskan dari persangkaan. Dalam setiap kasus yang terkait dengan HAM khususnya kebebasan berpendapat sering kali terjadi benturan antara hak individu yang harus dihormati dan hak kebebasan berekspresi, "...there were competing human rights to be balanced, namely the individual's right to respect for private and family life, and the media's right to freedom of expression... ",

Jika, kebebasan berpendapat dianggap sebagai salah satu HAM yang sangat strategis dalam menompang jalan dan bekerjanya demokrasi serta sulit membayangkan sistem demokrasi bisa bekerja tanpa adanya kebebasan menyatakan pendapat, sikap, dan berekspresi. Maka, kita tidak dapat menutupi bahwa berbagai kejahatan khususnya tindak pidana yang terjadi terkait dengan penyampaian pendapat melalui media elektronik merupakan

\footnotetext{
${ }^{8}$ Dame Mary Arden, 2017, "Human rights", Cambridge Law Jurnal (Westlaw), C.L.J. 2017, 76(3), 469-472.
}

suatu keresahan bagi masyarakat yang terkena dampaknya.

Berdasarkan uraian di atas, maka melalui tulisan ini akan dijelaskan mengenai "Batasan Kebebasan Berpendapat Melalui Media Elektronik Dalam Perspektif Hak Asasi Manusia Dikaitkan Dengan Tindak Pidana Menurut Undang - Undang Nomor 11 Tahun 2008 Tentang Informasi Dan Transaksi Elektronik Dan Undang Undang Nomor 19 Tahun 2016 Tentang Perubahan Atas Undang Undang Nomor 11 Tahun 2008 Tentang Informasi Dan Transaksi Elektronik".

Dalam uraian yang telah dikemukakan di atas, maka dapat kiranya penulis merumuskan apa yang menjadi masalah pokok dalam penelitian ini, yaitu:

1. Bagaimana batasan kebebasan berpendapat melalui media elektronik dilihat dari perspektif Hak Asasi Manusia dikaitkan dengan tindak pidana?

2. Bagaimana pengaturan yang ideal tentang batasan kebebasan berpendapat melalui media elektronik dilihat dari perspektif Hak Asasi Manusia dikaitkan dengan tindak pidana?

Penelitian ini memfokuskan diri pada studi kepustakaan dan doktrin hukum. Doktrin hukum yang digunakan dalam penelitian ini ialah 
doktrin hukum progresif. Penelitian yuridis normatif dimaksudkan untuk mengetahui pengaturan kebebasan berpendapat melalui media elektronik. Teknik analisis data yang digunakan dalam penelitian ini adalah teknik analisis kualitatif.

\section{Hasil Dan Pembahasan}

\section{Batasan}

\section{kebebasan}

\section{Berpendapat melalui Media} Elektronik

Perkembangan dan kemajuan teknologi informasi demikian pesat telah menyebabkan perubahan kegiatan kehidupan manusia dalam berbagai bidang yang secara langsung telah mempengaruhi lahirnya bentuk - bentuk perbuatan hukum yang baru. ${ }^{9}$ Hal ini tentunya membawa dampak besar bagi kehidupan masyarakat khususnya di wilayah Indonesia. Semakin teknologi informasi mudah diakses, dan pengguna bertambah, tentu melahirkan banyak harapan sekaligus tantangan. ${ }^{10}$ Persoalan ini semakin mengemuka karena beberapa kasus terkait dengan kebebasan berpendapat dengan memanfaatkan teknologi informasi dalam hal ini media elektronik dianggap belum terselesaikan secara adil.

Terkait dengan kebebasan

\footnotetext{
${ }^{9}$ Salah satu pertimbangan pemerintah dalam pembentukan UU ITE dapat dilihat di dalam UU ITE

10 Wahyudi Djafar, "Mengintegrasikan HAM dan Internet", Kompas, 21 Agustus 2014
}

elektronik, Dewan HAM PBB menegaskan perlindungan hak yang dimiliki setiap orang saat offline juga melekat saat mereka online. Perlindungan ini khususnya terkait hak atas kebebasan berpendapat, yang berlaku tanpa melihat batasan atau sarana media yang dipilih. Hal ini diatur dalam ketentuan Pasal 19 Deklarasi Universal HAM dan Kovenan Internasional Hak Sipil dan Politik, yang telah diratifikasi Indonesia melalui UU No. 12 Tahun 2005. ${ }^{11}$ Dalam hal ini, pemerintah Indonesia berusaha untuk mengakomodasi kebebasan berpendapat dan sekaligus membatasi kebebasan berpendapat di media elektronik baik melalui KUHP maupun melalui Undang-Undang Nomor 11 Tahun 2008 Tentang Informasi Dan Transaksi Elektronik dan Undang - Undang Nomor 19 Tahun 2016 Tentang Perubahan Atas Undang - Undang Nomor 11 Tahun 2008 Tentang Informasi Dan Transaksi Elektronik dan didukung oleh perangkat negara baik eksekutif, legislatif, dan yudikatif khususnya Kementerian Komunikasi dan Informatika. $^{12}$

Ketentuan dalam KUHP menunjukkan bahwa kebebasan berpendapat yang dilakukan melalui segala saluran yang tersedia memiliki pembatasan. KUHP yang merupakan pembatasan kebebasan

\footnotetext{
${ }^{11}$ Ibid

${ }^{12}$ Paskalis Marvin, "Pembatasan Kebebasan Berpendapat dalam Media Sosial di Indonesia", www.academia.edu, Diakses Senin Tanggal 1 Juli 2018
} 
berpendapat secara umum.

Berdasarkan Putusan Mahkamah

Konstitusi yang telah dipaparkan,

Mahkamah Konstitusi telah

menghapus lima pasal haatzaai artikelen $^{13}$. Pasal-pasal tersebut terdapat dalam KUHP, yakni dalam Pasal Pasal 134, Pasal 136 bis, Pasal 137, Pasal 154 dan Pasal 155. Sementara Pasal 160 KUHP tetap diberlakukan dengan cara pandang yang berbeda, yakni sebagai delik materil tidak lagi sebagai delik formil. Meskipun Mahkamah Konstitusitelah menghapus lima pasal tersebut\& tetapi masih terdapat sejumlah pasal-pasal yangtergolong sebagai haatzaai artikelen dalam KUHP yang dapat mengancam kebebasan berpendapat. Pasal-pasal tersebut diantaranya Pasal 156, Pasal 157, dan Pasal 208 KUHP. ${ }^{14}$

$$
\text { Seperti yang telah }
$$

dikemukakan sebelumnya, bahwa terkait dengan kebebasan berpendapat di dalam KUHP Indonesia sebenarnya telah tertuang beberapa Pasal mulai dari Pasal 156 dan Pasal 157 KUHP, Pasal 160 161 KUHP, Pasal 207 dan 208 KUHP, hingga BAB XVI tentang Penghinaan yang terdiri dari Pasal 310 - 321 yang merupakan pasal umum terkait dengan kebebasan

13 Haatzaai artikelen adalah pasal-pasal dalam Kitab Undang-undang Hukum Pidana Indonesia (Wetboek van Strafrecht voor Indonesie, Koninklijk Besluit van 15 October 1915 Nr. 33, Staatsblad 1915 -732, jis 1917-497, 1917-645 — in werking getreden op 1 Januari 1918) tentang penyebaran kebencian sebagai akibat dari penghinaan terhadap Martabat Kerajaan ${ }^{14}$ Ibid berpendapat seperti pencemaran nama baik, penghinaan, fitnah, dan hasut namun tidak dikhususkan pada penggunaan dan pemanfaatan media elektronik.

Pemberdayaan budaya hukum merupakan tema sentral yang sangat relevan dengan upaya perlindungan HAM di Indonesia. Sejauh ini kondisi perlindungan HAM di Indonesia masih belum sesuai dengan harapan masyarakat. Pernyataan ini didukung oleh argumentasi berupa masih seringnya terjadi pelanggaran HAM di Indonesia. Pembuat kebijakan legislatif dalam pernyataan yang dicantumkan dalam penjelasan UU tentang HAM (UU No. 39/1999) mengakui bahwa pada kenyataannya selama lebih lima puluh tahun usia Republik Indonesia, pelaksanaan penghormatan, perlindungan, dan penegakan HAM masih jauh dari memuaskan. ${ }^{15}$ Adapun kebebasan berpendapat merupakan salah satu hak yang dimiliki oleh setiap manusia yang sampai hari ini dalam hal penghormatan, perlindungan, dan penegakannya tentu saja masih belum memuaskan.

Kebebasan berpendapat memiliki dimensi politik, bahwa kebebasan ini dianggap sebagai elemen esensial bagi keikutsertaan warga dalam kehidupan politik dan juga mendorong gagasan kritis dan

\footnotetext{
${ }^{15}$ R. B. Sularto dalam Muladi, 2009, Hak Asasi Manusia (Hakekat, Konsep, dan Implikasinya dalam Perspektif Hukum dan Masyarakat), Cet. III, Bandung: PT Refika Aditama, h. 266.
} 
perdebatan tentang kehidupan politik bahkan sampai soal kemenangan militer. ${ }^{16}$ Selain itu, kebebasan berpendapat erat kaitannya dengan demokrasi. Ia dianggap sebagai prasyarat bagi perwujudan prinsip transparansi dan akuntabilitas yang pada akhirnya sangat esensial bagi pemajuan dan perlindungan HAM. Kebebasan berpendapat juga menjadi pintu bagi dinikmatinya kebebasan berkumpul, berserikat dan pelaksanaan hak untuk memilih. ${ }^{17}$

Kebebasan berpendapat merupakan salah satu kategori hak asasi manusia yang utama. Hak ini masuk dalam kategori hak asasi pertama, hak dengan dimensi sipil politik. Meskipun hak berpendapat dianggap 'tidak' sefundamental hak atas hidup, hak beragama dan berkeyakinan, hak bebas dari penyiksaan, dan masih dimungkinan untuk diderogasi, hak ini selalu menjadi pengawal utama hak-hak dasar manusia. Sebagai bagian dari hak liberal, kebebasan berpendapat menjadi jembatan dari dua dimensi hak sipil (hak bebas dari intervensi negara) dan hak politik (hak untuk menentukan negara). Kebebasan berpendapat menjadi penanda dari suatu tatanan politik yang demokratis dan dasar supremasi hukum. ${ }^{18}$

\footnotetext{
${ }^{16}$ Vincenzo Zeno-Zencovich, 2008, Freedom of Expression: A Critical and Comparative Analysis, New York: Routledge-Cavendish, h. 1 .

${ }^{17}$ ICCPR/C/CG/34, Article 19: Freedom of Opinion and Expression, Human Rights Committee, 102nd session, Geneva, 11-29 July 2011, paragraph 3-4

${ }^{18}$ KontraS (Komisi untuk Orang Hilang dan Korban Tindak Kekerasan), "Menguji
}

Islam sebagai agama yang universal dan dianut oleh mayoritas masyarakat Indonesia, telah memberikan pedoman yang lengkap baik yang bersumber dari Al Quran, Al Hadis maupun ijtihad para ulama yang shahih, ${ }^{19}$ salah satunya tentang kewajiban untuk menyampaikan kebenaran dalam hal ini pendapat yang benar tanpa harus merasa takut meskipun itu pahit baginya "Kullil Haq'u Walaukana Muran" (QS. 4:135). Hal ini menyiratkan bahwa kebebasan berpendapat juga telah diatur dan dibolehkan menurut aturan Allah selama pendapat yang disampaikan itu benar dan bukan merupakan suatu kebohongan.

Setelah PBB memunculkan DUHAM 1948 yang secara konkret memaparkan standar - standar HAM yang harus dijaga dan dilaksanakan. Disinilah tonggak awal manusia mulai secara serius ingin menginplementasikan nilai - nilai HAM dengan cara mengikat diri dengan aturan dan norma yang telah dibuatnya dan diberlakukan secara universal. 20 Ketentuan terkait kebebasan berpendapat selanjutnya ditegaskan dalam ketentuan Pasal 19 International Covenant on Civil and Political Right (ICCPR).

Meskipun

kebebasan berpendapat dijamin oleh negara

\footnotetext{
Pembatasan terhadap Kebebasan Berekspresi dan Hak Berorganisasi yang Dimungkinkan Berdasarkan Perspektif HAM, www.kontras.org, Diakses Senin Tanggal 1 Juli 2018

${ }^{19}$ Emilda Firdaus, Op. Cit., h.62.

${ }^{20}$ Hamid Awaludin dalam Emilda Firdaus, Ibid
} 
sebagai salah satu HAM, namun ada hal yang membatasinya. pembatasan ini dilakukan dengan tetap menghormati beberapa prinsip, seperti misalnya alasan pembatasan HAM yang harus di defenisikan secara ketat dan bukan dalam kerangka mengurangi substansi penghormatan terhadap hak tersebut, penerapan pembatasan HAM tidak boleh secara sewenang - wenang dan diskriminatif, dan pembatasan harus dilakukan sesuai dengan prasyarat yang telah ditentukan oleh peraturan perundang - undangan tentang HAM. Adapun mekanisme dalam pembatasan HAM ini tidak melanggar hak - hak warga masyarakat. $^{21}$

Ketentuan mengenai syarat pembatasan terdapat di dalam berbagai peraturan perundang undangan antara lain, Pasal 29 ayat (2) DUHAM 1948, Pasal 21 dan Pasal 22 ayat (2) ICCPR, Pasal 70 undang - undang Nomor 39 Tahun 1999 tentang Hak Asasi Manusia, Pasal 73 undang - undang Nomor 39 Tahun 1999 tentang Hak Asasi Manusia, Pasal 28J ayat (2) UUD 1945, khusus untuk hak atas kebebasan berpendapat dalam menentukan batasan konsep dan cakupan jaminan hak atas kebebasan berpendapat, dapat dilihat di dalam Pasal 19 Deklarasi Universal Hak Asasi Manusia tahun 1948, Adapun secara eksplisit pembatasan

21 Eko Royadi, 2018, Hukum Hak Asasi Manusia (Perspektif Internasional, Regional, dan Nasional), Depok: PT Rajagrafindo Persada, h. 58 - 59. kebebasan berpendapat terdapat di dalam Pasal 20 ICCPR. ${ }^{22}$

Ketentuan Pasal 20 menjadi pagar pembatas dari kebebasan berpendapat [melengkapi ketentuan Pasal 19 ayat (3)]. ${ }^{23}$ Pembatasan ini sangat relevan misalnya untuk menangkal segala bentuk pendapat (tertulis, gambar, audio, dan sebagainya) yang menyerukan atau mempropagandakan perang. ${ }^{24} \mathrm{Hal}$ serupa juga dibenarkan untuk membatasi ruang gerak kebebasan berpendapat yang mengkampanyekan kebencian atas dasar kebangsaan, ras atau agama

${ }^{22}$ Ibid., h. $59-60$.

${ }^{23}$ Dalam ICCPR (art. 4) terdapat dua kluster besar hak asasi, hak-hak yang tidak bisa dibatasi atau dikurangi dalam situasi apapun (non-derogable rights) dan hak-hak yang bisa dibatasi atau dikurangi karena alasan situasional. Hak-hak non-derogable tersebut adalah: Hak-hak fundamental tersebut adalah: hak atas hidup (Pasal 6); bebas dari penyiksaan dan perlakuan tidak manusiawi (Pasal 7); bebas dari perbudakan dan kerja paksa [Pasal 8 (paragraf 1 dan 2)]; bebas dari pemidanaan karena perjanjian hutang piutang (Pasal 11); bebas dari berlakunya pemidanaan secara retroaktif (Pasal 15); hak atas pengakuan sebagai subjek hukum (Pasal 16); kebebasan berpikir, berkeyakinan, dan beragama (Pasal 18).

${ }^{24}$ Larangan propaganda perang ini lebih dalam konteks perang seperti yang dimaksud dalam Piagam PBB (UN Charter) sebagai ancaman atau agresi terhadap perdamaian. Ini artinya perang yang dimaksud merupakan konflik antar-negara atau berskala internasional dan bukan dalam konteks konflik bersenjata internal, kecuali yang terakhir ini bisa berkembang menjadi yang pertama. Propaganda perang dalam Pasal 20(1) ICCPR ini lebih didefinisikan sebagai upaya proganda untuk memobilisasi serangan ke negara lain. Lihat Manfred Nowak, 2005, U.N. Covenant on Civil and Political Rights; ICCPR Commentary, 2nd revised edition, N.P. Engel, Publisher, h. 473. 
yang merupakan hasutan untuk melakukan diskriminasi, permusuhan atau kekerasan (yang dikenal sebagai hate speech). Di berbagai negara derogasi terhadap hate speech tersebut bahkan dimasukkan dalam bentuk pemidanaan (untuk melengkapi sistem keperdataan) berdasarkan suatu legislasi nasional. ${ }^{25}$ Sementara beberapa negara lebih menerapkan upayaupaya preventif, seperti mencegah terjadinya rapat publik/massal yang mempropagandakan hate speech atau dengan melakukan pembubaran bisa sedang berlangsung. ${ }^{26}$

Terkait dengan pembatasan hak khususnya terkait dengan kebebasan berpendapat terdapat

${ }^{25}$ Tidak semua unsur hate speech dalam Pasal 20(2) juga menjadi subjek pemidanaan, bentuk kriminalisasi yang paling umum adalah yang berdasarkan kebencian rasial. Namun di beberapa negara hasutan untuk kebencian dan diskriminasi juga ditambah dengan kategori orientasi seksual (Swedia, Norwegia, Irlandia, Islandia, Prancis, Denmark, Kanada, dan Inggris). Hal tersulit untuk membangun demokrasi antara kebebasan berekspresi dan hate speech adalah bila dikaitkan dengan isu agama. Umumnya setiap agama punya klaim supremasi "kebenaran" ada di dalam dirinya sendiri dan lebih lanjut klaim tersebut punya konsekwensi generik untuk menarik orang dari keyakinan lain ke dalam keyakinannya sejauh tidak dilakukan lewat kekerasan atau pemaksaan. Menjadi persoalan bila hasutan dan kebencian terhadap "kelompok lain" yang bahkan disertai justifikasi kekerasan justru dianggap sebagai suatu keyakinan transendental atau relijius.

${ }^{26}$ KontraS (Komisi untuk Orang Hilang dan Korban Tindak Kekerasan), "Menguji Pembatasan terhadap Kebebasan Berekspresi dan Hak Berorganisasi yang Dimungkinkan Berdasarkan Perspektif HAM, www.kontras.org, Diakses Senin Tanggal 1 Juli 2018 persamaan batasan antara satu aturan dengan aturan yang lain maka dapat ditarik suatu asumsi bahwa batasan kebebasan berpendapat adalah sebagai berikut:

a. Dilakukan berdasarkan hukum.

b. Penghormatan terhadap hak kebebasan orang lain.

c. Untuk memenuhi keadilan dan kepentingan umum sesuai dengan pertimbangan moral, keamanan, dan ketertiban umum dalam suatu masyarakat demokratis.

d. Tidak mengandung unsur propaganda.

e. Bersifat informatif dan bermanfaat.

Singkatnya, bahwa HAM juga memiliki batasan khususnya hak yang diberikan terkait dengan kebebasan berpendapat. Dalam mengemukakan pendapat seorang pemegang hak harus tunduk dengan aturan hukum yang berlaku dan juga harus menghormati hak yang dimiliki orang lain jangan sampai dalam menyampaikan pendapat seseorang menyalahi wilayah kebebasan orang lain yang nantinya dapat mengganggu keamanan dan ketertiban umum.

Pada prinsipnya setiap orang berhak untuk menyuarakan aspirasi dan mengekspresikan kebebasan berpendapatnya. Hal ini di atur di dalam Undang - Undang No. 9 Tahun 1998 tentang Kebebasan 
Menyampaikan Pendapat di Muka Umum. ${ }^{27}$

Pembatasan kebebasan

berpendapat melalui media

elektronik secara spesifik dituangkan

dalam kebijakan di bidang

komunikasi yang terdapat dalam

Undang-Undang Nomor Undang-

Undang Nomor 11 Tahun 2008

Tentang Informasi Dan Transaksi

Elektronik dan Undang - Undang

Nomor 19 Tahun 2016 Tentang

Perubahan Atas Undang - Undang

Nomor 11 Tahun 2008 Tentang Informasi Dan Transaksi Elektronik.

\section{Pengaturan yang Ideal tentang Batasan Kebebasan \\ Berpendapat melalui Media Elektronik}

Kebijakan atau upaya penanggulangan kejahatan (criminal policy) pada hakikatnya merupakan bagian integral dari upaya perlindungan masyarakat (social defence) dan upaya mencapai kesejahteraan masyarakat (social welfare). Oleh karena itu dapat dikatakan bahwa tujuan akhir atau tujuan utama dari politik kriminal adalah perlindungan masyarakat. ${ }^{28}$ Kebijakan kriminal dilaksanakan dengan dua cara yaitu sarana penal (fungsionalisasi hukum) dan sarana non penal (fungsionalisasi non hukum pidana). Sarana penal diartikan sebagai kebijakan penanggulangan kejahatan dengan memfungsikan eksistensi hukum pidana untuk menanggulanginya.

${ }^{27}$ Eko Riyadi, Op. Cit., h. 64.

${ }^{28}$ Emilda Firdaus, Op. Cit., h. 79.
Sedangkan sarana non penal dilakukan dengan cara memfungsikan semua aspek selain hukum pidana seperti aspek hukum perdata atau hukum administrasi negara dengan kata lain sarana non penal tidak menggunakan sarana penal (prevention without punishment). ${ }^{29}$

Perkembangan teknologi telekomunikasi dan informasi saat ini sangat berbeda dengan beberapa tahun yang lalu. Berbagai informasi telah dapat disajikan secara mudah dan canggih. Semua orang di belahan dunia dapat terhubung satu sama lain tanpa harus bertemu secara face to face, kondisi demikian merupakan pertanda dimulainya era cyber. ${ }^{30}$

Setiap Perkembangan positif dari teknologi informasi tentu saja tidak pernah lepas dari aspek negatif. Perkembangan teknologi informasi mendorong lahirnya kejahatan kejahatan baru yang disertai dengan modus operandi yang baru sama sekali. Maka tak heran jika dikatakan bahwa kejahatan tumbuh dan berkembang mengikuti perkembangan masyarakat, atau dengan kata lain seseungguhnya masyarakatlah yang menyebabkan terjadinya suatu kejahatan (crime is a product of society its self). Akibat lanjutan yang tak bisa dihindari adalah hukum pidana sebagai salah satu instrument pengendalian

\footnotetext{
${ }^{29}$ Mahrus Ali, 2012, Dasar-Dasar Hukum Pidana, Cet. II, Jakarta: Sinar Grafika, h. 239.

30 Niniek Suparni, 2009, Cyberspace Priblematika \& Antisipasi Pengaturannya, Jakarta: Sinar Grafika, h. 1.
} 
kejahatan dituntut untuk juga meng update dan mengkreasikan dirinya agar mampu mengimbangi laju kejahatan yang sedemikian rupa. Sebab jika tidak, maka eksistensinya tidak banyak diharapkan khususnya di dalam menanggulangi kejahatan kejahatan yang ada hubungannya dengan penggunaan teknologi informasi. ${ }^{31}$

Dalam hal kebebasan berpendapat melalui media elektronik, pemerintah Indonesia sudah mengambil langkah yang tepat dengan hadirnya Undang-Undang Nomor 11 Tahun 2008 Tentang Informasi Dan Transaksi Elektronik dan Undang - Undang Nomor 19 Tahun 2016 Tentang Perubahan Atas Undang - Undang Nomor 11 Tahun 2008 Tentang Informasi Dan Transaksi Elektronik terlepas dari pro dan kontra di dalam masyarakat terkait dengan lahirnya undang undang ini yang sebagian menganggap bahwa dengan undang - undang ini negara mengekang kebebasan berpendapat. Undang undang ini tentu saja berbeda dengan KUHP, perundang - undangan ini telah sedemikian rupa mengantisipasi efek negatif perkembangan teknologi informasi khususnya media elektronik seperti mengatur antisipasi jenis dan bentuk kejahatan dengan menggunakan kecanggihan teknologi informasi. ${ }^{32}$ Meskipun masih terdapat kelemahan di dalam undang - undang ini, namun setidaknya negara telah memberi perlindungan

\footnotetext{
${ }^{31}$ Mahrus Ali, Op. Cit., h. 251.

${ }^{32}$ Ibid., h. 254.
}

hak warga negara dalam bentuk peraturan perundang - undangan.

Selain melindungi warga negaranya dari penyalahgunaan teknologi informasi khususnya media elektronik, Indonesia juga melindungi kebebasan berpendapat bagi setiap warganya dengan mengesahkan Konvensi Internasional Tentang Hak Sipil Dan Politik yang di dalamnya terdapat kebebasan menyampaikan pendapat sebagai salah satu hak sipil yang dimiliki setiap warga negara. Konvensi tersebut disahkan dengan Undang Undang Nomor 12 Tahun 2005 tentang Pengesahan International Covenant On Civil And Political Rights (Kovenan Internasional Tentang Hak Sipil Dan Politik).

Konsekuensi hukum telah diratifikasinya ICCPR oleh Indonesia, Negara Indonesia memiliki tanggungjawab atas perlindungan dan pemenuhan semua hak dan kebebasan yang dijanjikan di dalam ICCPR. Perlindungan dan pemenuhan kewajiban hak - hak dan kebebasan dalam ICCPR oleh negara adalah bersifat mutlak dan harus segera dijalankan (immediately) dan justiciable. $^{33}$

Lahirnya berbagai peraturan perundang - undangan yang melindungi HAM khususnya kebebasan berpendapat, seperti Undang - Undang Nomor 9 tahun 1998 Tentang Kemerdekaan Menyampaikan Pendapat di Muka

\footnotetext{
${ }^{33}$ Apeles Lexi Lonto, dkk, 2015, Hukum Hak Asasi Manusia, Yogyakarta: Penerbit Ombak, h. 38.
} 
Umum, Undang - Undang Nomor 11 Tahun 2008 Tentang Informasi Dan Transaksi Elektronik, Undang Undang Nomor 19 Tahun 2016 Tentang Perubahan Atas Undang Undang Nomor 11 Tahun 2008 Tentang Informasi Dan Transaksi Elektronik, dan Undang - undang Nomor 40 Tahun 1999 tentang Pers merupakan ragam peraturan yang dalam satu waktu menjamin namun di waktu yang lain ia membatasi kebebasan berpendapat di Indonesia. Munculnya undang-undang tersebut sebagai implikasi dari gejolak masyarakat dan perkembangan zaman yang menuntut pemerintah untuk menentukan kebijakan yang sesuai dengan masyarakat dalam kebebasan berpendapat. Pemerintah diharapkan mampu untuk mengambil kebijakan berkaitan dengan kebebasan berpendapat dalam masyarakat. Selain menjamin kebebasan berpendapat, undangundang tersebut mengatur mengenai pembatasan kebebasan berpendapat yang sesuai dengan ketentuan DUHAM, ICCPR, dan Pasal 28J UUD $1945 .^{34}$

Tidak dapat dipungkiri bahwa pemerintah melalui regulasi tersebut telah berusaha untuk mengatur realitas berdasarkan dinamika masyarakat sekarang ini. Permasalahan yang terjadi adalah tolok ukur daripada pencemaran nama baik dan penyebaran berita

\footnotetext{
${ }^{34}$ Paskalis Marvin, "Kebebasan Berpendapat melalui Media Sosial di Indonesia", www.academia.edu, Diakses Selasa Tanggal 3 Juli 2018
}

bohong atau merupakan sebuah kritik. Pencemaran nama baik berkaitan dengan informasi yang berupa opini yang diberitakan oleh satu pihak mengenai pihak lain dan cenderung berisi keburukan pihak lain, namun meskipun itu hanya opini atau luapan emosional saja namun, dampak yang ditimbulkan sangat luas dan luar biasa dirasakan oleh para pengguna media elektronik dari berbagai kalangan, sebab pikiran mereka yang membaca mengenai keburukan orang lain menjadi terprovokasi baik itu setuju dengan opini ataupun menentang opini tersebut. Disamping itu, perspektif masing-masing subjek baik yang menuliskan pernyataan maupun yang mendapatkan informasi tersebut sangat sering berbeda dan menghasilkan banyak perspektif dan pergeseran makna. Hal ini dikarenakan tidak jernihnya suatu informasi yang diterima dari suatu media oleh penerima informasi. Dinamika yang mungkin sering terjadi namun tidak disadari adalah saat pengguna media sosial mendapatkan suatu informasi dan kemudian menyebarkan ulang informasi (repost) tersebut meskipun kebenaran dari informasi tersebut belum jelas. ${ }^{35}$

Beberapa kasus terkait dengan kebebasan berpendapat melalui media elektronik seperti kasus Prita Mulyasari tahun 2009 dan Mukhadly (Acho) tahun 2017 menunjukkan ada yang kurang dalam

${ }^{35}$ Ibid 
penegakan hukum. Secara substansi hukum UU ITE sudah cukup baik dengan mengadopsi prinsip - prinsip yang terdapat di dalam DUHAM, ICCPR, dan Pasal 28J UUD 1945 yang disinkronkan dengan Pancasila. Selain itu, ketentuan di dalam UU ITE bertujuan untuk menjaga keseimbangan antara kebebasan dan perlindungan individu, keluarga, kehormatan, dan martabat dengan kebebasan mengemukakan pendapat dan pikiran dalam suatu masyarakat yang demokratis. Namun beberapa pasal seringkali multitafsir dan berpotensi sebagai alat untuk menghukum seseorang. Selain itu, perlu pembenahan terhadap struktur hukum yang ada sebab tanpa struktur hukum yang baik pula, perlindungan kebebasan berpendapat melalui media elektronik hanya menjadi sekedar wacana belaka.

Sebagai jalan tengah hingga hari ini keberadaan UU ITE masih dipertahankan, namun dengan catatan dilakukan perbaikan atau perubahan. Beberapa organisasi masyarakat sipil mendorong upaya perbaikan pada pasal-pasal yang dianggap krusial. Beberapa diantaranya: Pasal 27 yang mengatur tentang pencemaran nama baik dan Pasal 28 yang mengatur tentang perbuatan yang menyentuh isu suku, agama, ras, dan antargolongan (SARA). Hal ini sangat penting karena pasal-pasal tersebut seringkali multitafsir dan berpotensi sebagai alat untuk menghukum seseorang karena dianggap melakukan pencemaran nama baik atau penodaan agama. ${ }^{36}$ Sebut saja opini yang tersistematis melalui media elektronik yang muatannya berunsurkan SARA, dapat dijadikan sebagai pelanggaran Pasal 28 ayat (2) oleh oknum yang tidak menyukai muatan media elektronik tersebut. Namun disisi lain, opini tersebut dapat membuka pandangan serta wawasan masyarakat, khususnya penggunaan media elektronik. Maka dimungkinkan terjadinya suatu tuntutan yang hanya menilai secara subjektif dan kedua pasal yang telah dipaparkan disalahgunakan untuk menimbulkan suatu ketegangan dalam masyarakat seperti memicu konflik sosial. Elastisitas kedua aturan tersebut berujung kekaburan mengenai maksud sesungguhnya dari pembuat undang-undang. ${ }^{37}$

Sebenarnya, telah ada Perubahan atas UU ITE yang berlaku yaitu Undang - Undang Nomor 19 Tahun 2016 Tentang Perubahan Atas Undang - Undang Nomor 11 Tahun 2008 Tentang Informasi Dan Transaksi Elektronik. ${ }^{38}$ Namun, perubahan revisi UU ITE sebenarnya tidak memberikan perubahan signifikan. Justru di sisi lain dapat dilihat sebagai penambahan beberapa persoalan prinsipil, seperti munculnya potensi penyalahgunaan wewenang pemerintah karena diperluasnya kewenangan dalam

\footnotetext{
${ }^{36}$ https://elsam.or.id, diakses Selasa Tanggal 3 Juli 2018

${ }^{37}$ Paskalis Marvin, "Kebebasan Berpendapat melalui Media Sosial di Indonesia", $O p$. Cit., diakses Selasa Tanggal 3 Juli 2018

38 https://kompas.com, Diakses Selasa Tanggal 3 Juli 2018
} 
mengontrol aktivitas dunia cyber. Hal ini akan menyinggung lagi persoalan kebebasan berpendapat, berekspresi bahkan hak untuk mendapat informasi, jika tidak diatur dengan jelas dan terukur. ${ }^{39}$ UU ITE tampaknya masih mengundang kritik terutama berkaitan dengan pasal penghinaan dan/atau pencemaran nama baik yang diatur dalam Pasal 27 ayat (3) UU ITE.

Secara umum, baik sebelum direvisi maupun setelah direvisi, Pasal 27 ayat (3) UU ITE tetap dinilai oleh banyak pihak membatasi kebebasan berpendapat atau berekspresi sebab sifatnya yang dinilai masih multitafsir. Perubahan yang dilakukan terhadap Pasal 27 ayat (3) sifatnya hanya mengurangi orang yang di tahan sebelum melalui proses pengadilan tapi tidak mengurangi kasus yang terjadi terkait. Beberapa ketentuan dalam UU ITE berpotensi menjadikan masyarakat takut untuk bersikap kritis karena khawatir dianggap menghina atau mencemarkan nama baik.

Sejak diundangkan pada tahun 2008, UU ITE sudah beberapa kali memakan korban. ${ }^{40}$ Bberapa kasus yang merupakan aduan pencemaran nama baik melalui media elektronik dalam hal ini media sosial sebagian besar dilatar

\footnotetext{
${ }^{39}$ Petrus Richard Sianturi, "Setelah Revisi Undang - Undang ITE Disahkan", https://geotimes.co.id, Diakses Rabu Tanggal 4 Juli 2018

40 https://elsam.or.id, Diakses Selasa Tanggal 3 Juli 2018
}

belakangi oleh ungkapan ekspresi. ${ }^{41}$ Kasus-kasus tersebut tidak semuanya memiliki akibat hukum yang mengikat sebagaimana diatur dalam pasal 27 ayat (3) yaitu penjara dan denda. Bahkan tidak ada yang dihukum penuh sebagaimana aturan pasal tersebut. ${ }^{42}$

Dalam sejumlah kasus beberapa orang terkena jeratan pasal penghinaan dan/atau pencemaran nama baik hanya karena mengeluh terhadap kondisi yang dialaminya seperti kasus yang dialami Prita Mulyasari tahun 2009 dan seorang komika stand up comedy Mukhadly (Acho) yang baru saja terjadi di tahun 2017. Terkait dengan kasus UU ITE, akan diuraikan dua contoh kasus sebelum dan setelah perubahan UU ITE dilakukan, yaitu sebagai berikut:

1. Kasus Prita Mulyasari Tahun 2009, permasalahan terjadi karena hal yang sifatnya sepele, yaitu pengalaman tidak menyenangkan Prita sebagai seorang pasien dari sebuah rumah sakit, berkirim email pada temannya terkait dengan pengalaman kurang menyenangkan yang didapatkannya, namun tanpa diduga berdampak hukum dengan dijerat UndangUndang Nomor 11 Tahun 2008 tentang Informasi dan Transaksi Elektronik,

\footnotetext{
${ }^{41}$ Mufti Nurlatifah, "Ancaman Kebebasan Berekspresi di Media Sosial”, ResearchGate, 1 April 2018, h. 8.

${ }^{42}$ Ibid, h. 8 - 9.
} 
sehingga harus mendekam di penjara.

2. Kasus Mukhadly (Acho) seorang artis stand up comedy yang dianggap telah melakukan pencemaran nama baik dan fitnah karena curhat soal fasilitas apartemen di blog pribadinya. Acho dipolisikan pihak pengembang Apartemen Green Pramuka, Cempaka Putih, Jakarta Pusat. Kasus Acho bermula saat dia menuliskan kekecewaannya terkait fasilitas yang disediakan pengembang Apartemen Green Pramuka, Cempaka Putih, Jakarta Pusat, di blog pribadinya muhadkly.com.

Jika merujuk dari batasan kebebasan berpendapat yang telah diuraikan sebelumnya, kedua kasus tersebut tidak melanggar satu pun dari batasan kebebasan berpendapat. Yang telah dilakukan baik Prita maupun Acho murni hanya untuk menggunakan hak berpendapatnya melalui media elektronik dengan tujuan memberikan informasi yang benar berdasarkan pengalamannya yang dibagikan kepada orang lain agar tidak ada lagi yang mengalami hal yang sama dengan mereka. Mereka menyampaikan pendapatnya juga bukan sekedar argumentasi tanpa dasar sebab mereka memiliki bukti atas kasus yang menimpa mereka.

Beberapa kasus lain selain kasus yang menimpa Prita dan Acho tentu saja menimpa beberapa orang bahkan ada masyarakat yang tetap terkena jeratan pasal ini walaupun tidak menyebutkan sama sekali nama yang dikeluhkan. ${ }^{43}$ Kondisi demikian yang membuat masyarakat khawatir UU ITE hanya akan menciptakan ketakutan dan membungkam daya kritis masyarakat sipil. Apabila dijalankan tanpa batasan yang jelas, UU ini dipandang berpotensi digunakan untuk praktik penyalahgunaan kekuasaan (abuse of power), misalnya ditafsirkan sesuai keinginan penguasa atau pihak yang berkepentingan untuk memidanakan seseorang.

Dari kasus yang sudah ada, masalah utamanya adalah sulitnya untuk membedakan mana kritik, mana koreksi dan mana tindakan pencemaran. Jika melihat kasus yang menimpa Prita tahun 2009 dan kasus yang menimpa Acho tahun 2017 dapat dikatakan bahwa sebelum dan setelah dilakukannya perubahan atas UU ITE belum memberikan perubahan yang signifikan untuk meminimalisir terjadinya kriminalisasi terhadap kebebasan berpendapat. Kegagalannya jika aturan tersebut menjadi sebuah "pasal karet", bisa elastis mengikuti kepentingan. Kasus yang terjadi di atas, sangat dimungkinkan pangkalnya pada pasal yang masih elastis tersebut. Dari pola kasus yang ada, elastisitas tersebut cenderung mudah dimanfaatkan pihak berkuasa salah satunya membungkam

\footnotetext{
43 https://mediaindonesia.com, Diakses Selasa Tanggal 3 Juli 2018
} 
kebebasan berpendapat, khususnya dalam mengungkap sebuah kekeliruan. Hal ini tegas mengatakan, bahwa ada urgensi untuk mengulas kembali untuk memberikan sebuah ketegasan dan prosedur yang jelas atas poin-poin yang memiliki kemungkinan untuk disalah artikan. ${ }^{44}$

Jika UU ITE dianggap mengekang kebebasan berpendapat khususnya melalui media elektronik, undang-undang ini tentu saja juga memiliki kelebihan yakni mengantisipasi kemungkinan penyalahgunaan media elektronik. Selain itu, undang-undang ini juga tidak hanya membahas mengenai pencemaran nama baik, fitnah, berita bohong atau masalah asusila, melainkan ada banyak konten lainnya mengenai aturan hidup di dunia maya dan transaksi yang terjadi di dalamnya yang diatur dengan rinci dalam UU ITE. Namun, tentu saja pemerintah tidak dapat menutup mata bahwa masih perlu dilakukan pembenahan terhadap UU ITE khususnya pasal - pasal terkait dengan kebebasan berpendapat yang masih memerlukan ketentuan yang lebih rinci. ${ }^{45}$

UU ITE terkait kebebasan berpendapat melalui media elektronik, ada baiknya UU ITE

${ }^{44}$ Randi Eka, Urgensi Perombakan Pasal 27 UU ITE, https://dailysocial.id, Diakses Kamis Tanggal 19 Juli 2018

45 Mohd. Sabri Bin Mamat, 2010, Kebebasan Berpendapat dalam Hukum Indonesia dan Malaysia, Jakarta: Skripsi Fakultas Syariah dan Hukum Universitas Islam Negeri Syarif Hidayatullah, h. $56-$ 57. tidak lagi mengatur pemidanaan pencemaran nama baik, tapi lebih fokus ke soal hukum media elektronik secara keseluruhan. Pemidanaannya seharusnya tidak perlu masuk UU ITE. Sebab aturan pencemaran nama baik sudah ada di dalam KUHP hanya saja tidak mengatur media penyebarannya. UU ITE sebagai politik/kebijakan hukum pidana seharusnya jauh lebih maju dari KUHP. Sehingga aturan terkait kebebasan berpendapat melalui media elektronik seperti pasal pencemaran nama baik dan penghinaan dipindahkan ke Rancangan KUHP. Dengan kata lain, sebaiknya UU ITE menghapus seluruh bentuk duplikasi pengaturan pidana khususnya pencemaran nama baik dan sepenuhnya dikembalikan pada KUHP beriringan dengan pembahasan pembaharuan Kitab Undang-undang Hukum Pidana.

Dalam pembenahan pasal terkait kebebasan berpendapat khususnya terkait dengan pencemaran nama baik, fitnah, dan sejenisnya diharapkan nantinya dapat mengatur mengenai hak-hak yang dapat dimiliki oleh seseorang sebagai pengguna atau penikmat teknologi informasi khususnya media elektonik agar dapat melaksanakan hak pribadinya tanpa rasa takut. Sebab dengan hanya mengatur mengenai kewajiban yang harus ditaati, maka pengguna akan buta terhadap hak yang dapat dimilikinya, sehingga akan menciptakan perasaan takut dan kekhawatiran dalam menggunakan hak kebebasannya untuk 
menyampaikan pendapat. Jelaslah hal ini akan terkait dengan hak pribadi seseorang. 46 Sehingga nantinya pasal yang terkait dapat memberikan kejelasan hukum dan bukan justru mencederai kebebasan berpendapat yang ingin diwujudkan. ${ }^{47}$ Pemerintah dalam peraturan pelaksanaannya, yakni dalam petunjuk pelaksanaan dan petunjuk teknisnya merinci tentang kebencian, kebohongan, dan pencemaran sebab hal - hal tersebut harus ditegaskan.

Penegasan yang dimaksud adalah harus dapat membedakan antara mengkritik atau memang menyebarkan berita atau informasi yang tidak benar sekedar opini belaka atau berdasar. Sebab jika informasi yang disampaikan benar maka tidak dapat dikategorikan sebagai pencemaran nama baik. Adapun benar dalam hal ini dapat diartikan sebagai berikut:
a) Dapat
dibuktikan kebenarannya
b) Berdasarkan pengalaman pribadi yang dapat dipertanggungjawabkan
c) Jika berdasarkan pengalaman orang lain harus diteliti dan dikaji terlebih dahulu
d) Bertujuan untuk kemaslahatan orang banyak

\footnotetext{
${ }^{46}$ Aris Setyo Nugroho, 2010, Perlindungan Kebebasan Berpendapat melalui Media Internet dalam Undang - Undang No. 11 Tahun 2008 tentang Informasi dan Transaksi Elektronik ditinjau dari Perspektif Hak Asasi Manusia, Surakarta: Fakultas Hukum Universitas Sebelas Maret, h. 53.

${ }^{47}$ Mufti Nurlatifah, Op. Cit., , h. 13.
}

e) Tidak mengandung unsur propaganda yang dapat mengganggu keamanan dan ketertiban umum

$$
\text { Kedepannya pemerintah }
$$

untuk meminimalisir terjadinya multitafsir, nantinya pasal - pasal terkait kebebasan berpendapat juga harus memasukkan batasan di dalam KUHP. Hendaknya pemerintah menetapkan pula upaya preventif (pencegahan) dalam mengatasi maraknya kasus hate speech dan hoax di dunia maya, khususnya pada generasi muda yang memiliki tingkat ketergantungan tinggi pada media elektronik. Selain itu, hendaknya penegak hukum bersikap tegas dan pro-aktif dalam mengatasi kasuskasus hate speech dan hoax pada media elektronik terutama yang berkaitan dengan keutuhan negara dan menjadi perhatian publik. ${ }^{48}$

Setelah disahkan nantinya langkah yang harus diambil pemerintah mengkampanyekan digital literacy kepada seluruh anggota masyarakat agar tidak salah kaprah dalam menggunakan teknologi yang tentunya dapat berakibat pada kontra produktif-nya peraturan yang telah ada. ${ }^{49}$

\footnotetext{
${ }^{48}$ Putu Eva Ditayani Antari, 2017, “Tinjauan Yuridis Pembatasan Kebebasan Berpendapat pada Media Sosial di Indonesia", Jurnal Hukum Undiknas, Vol. 4 No. 1.

49 Peiroll Gerard Notanubun, 2014, "Tinjauan Yuridis terhadap Kebebasan Berbicara dalam Ketentuan Pasal 27 Ayat 3 UU Nomor 11 Tahun 2008 Tentang ITE dalam Hubungan dengan Pasal 28 UUD 1945", Mimbar Keadilan (Jurnal Ilmu Hukum), Edisi: Mei - Nopember 2014
} 
Adapun dalam penerapannya, penegak hukum, dalam hal ini kepolisian harus berhati - hati dalam menggunakan pasal di dalam UU ITE khususnya terkait dengan kebebasan berpendapat. Kepolisian harus benar - benar memperhatikan dan melihat unsur - unsur pelanggaran dengan teliti. Kepolisian harus cermat dan bijaksana dalam menentukan seseorang hanya sekedar mengkritik atau memang menyebarkan berita atau informasi yang tidak benar sekedar opini belaka atau berdasar.

Untuk lembaga atau badan yang menangani secara khusus terkait dengan penyalahgunaan media elektronik atau kejahatan yang bisa saja terjadi dalam penggunaan media elektronik dalam hal ini Badan Siber dan Sandi Negara (BSSN) diharapkan dapat menyelesaikan kasus - kasus terkait dengan penyalahgunaan media elektronik khususnya kebebasan berpendapat secara tegas dan bijaksana.

\section{Kesimpulan}

Sebagai akhir penelitian ini, maka penulis dapat menarik beberapa kesimpulan yaitu:

1. Kebebasan berpendapat dijamin oleh negara sebagai salah satu HAM, namun ada hal yang membatasinya. pembatasan ini dilakukan dengan tetap menghormati beberapa prinsip, seperti:
a. Dilakukan berdasarkan hukum

b. Penghormatan terhadap hak kebebasan orang lain

c. Untuk memenuhi keadilan dan kepentingan umum sesuai dengan pertimbangan moral, keamanan, dan ketertiban umum dalam suatu masyarakat demokratis

d. Tidak mengandung unsur propaganda, ujaran kebencian, ataupun hasutan yang ditujukan untuk menyebarkan permusuhan, diskriminasi, atau kekerasan

e. Bersifat informatif dan bermanfaat.

2. Pengaturan yang ideal tentang batasan kebebasan berpendapat melalui media elektronik dilihat dari perspektif Hak Asasi Manusia dikaitkan dengan tindak pidana:

UU ITE tidak lagi mengatur pemidanaan pencemaran nama baik, tapi lebih fokus ke soal hukum media elektronik secara keseluruhan. Pemidanaannya seharusnya tidak perlu masuk UU ITE. Sebab aturan pencemaran nama baik sudah ada di dalam KUHP hanya saja tidak mengatur media penyebarannya.. Sehingga aturan terkait kebebasan berpendapat melalui media elektronik seperti pasal pencemaran nama baik dan penghinaan dipindahkan ke Rancangan KUHP. Adapun untuk meminimalisir terjadinya multitafsir, di dalam pasalnya 
harus dituangkan batasan kebebasan berpendapat.

\section{Daftar Pustaka}

\section{Buku}

Ani W. Soetjipto, 2015, HAM dan

Politik Internasional: Sebuah

Pengantar, Jakarta: Yayasan

Putra Obor Indonesia.

Apeles Lexi Lonto, dkk, 2015, Hukum Hak Asasi Manusia, Yogyakarta: Penerbit Ombak.

Eko Royadi, 2018, Hukum Hak Asasi Manusia (Perspektif

Internasional, Regional, dan Nasional), Depok: PT Rajagrafindo Persada.

Emilda Firdaus, 2015, Perlindungan Perempuan Korban KDRT Menurut HAM di Indonesia, Yogyakarta: Genta Publishing.

Mahrus Ali, 2012, Dasar - Dasar Hukum Pidana, Cet. II, Jakarta: Sinar Grafika, Jakarta.

Manfred Nowak, 2005, U.N. Covenant on Civil and Political Rights; ICCPR Commentary, 2nd revised edition, N.P. Engel, Publisher.

Muladi, 2009, Hak Asasi Manusia (Hakekat, Konsep, dan Implikasinya dalam Perspektif Hukum dan Masyarakat), Cet. III, Bandung: PT Refika Aditama.

Niniek Suparni, 2009, Cyberspace Problematika \& Antisipasi Pengaturannya, Jakarta: Sinar Grafika.

Nurul Qamar, 2016, Hak Asasi Manusia dalam Negara Hukum Demokrasi, Jakarta: Sinar Grafika.

Vincenzo Zeno-Zencovich, 2008, Freedom of Expression: A Critical and Comparative Analysis, New York: RoutledgeCavendish.
Majalah, Jurnal, Artikel dan Surat Kabar

Aris Setyo Nugroho, 2010, Perlindungan Kebebasan Berpendapat melalui Media Internet dalam Undang - Undang No. 11 Tahun 2008 tentang Informasi dan Transaksi Elektronik ditinjau dari Perspektif Hak Asasi Manusia, Surakarta: Fakultas Hukum Universitas Sebelas Maret.

Dame Mary Arden, 2017, "Human rights", Cambridge Law Jurnal (Westlaw), C.L.J. 2017, 76(3), 469-472.

Mohd. Sabri Bin Mamat, 2010, Kebebasan Berpendapat dalam Hukum Indonesia dan Malaysia, Jakarta: Skripsi Fakultas Syariah dan Hukum Universitas Islam Negeri Syarif Hidayatullah.

Mufti Nurlatifah, "Ancaman Kebebasan Berekspresi di Media Sosial", ResearchGate, 1 April 2018.

Peiroll Gerard Notanubun, 2014, "Tinjauan Yuridis terhadap Kebebasan Berbicara dalam Ketentuan Pasal 27 Ayat 3 UU Nomor 11 Tahun 2008 Tentang ITE dalam Hubungan dengan Pasal 28 UUD 1945", Mimbar Keadilan (Jurnal Ilmu Hukum), Edisi: Mei - Nopember 2014

Putu Eva Ditayani Antari, 2017, "Tinjauan Yuridis Pembatasan Kebebasan Berpendapat pada Media Sosial di Indonesia", Jurnal Hukum Undiknas, Vol. 4 No. 1

Wahyudi Djafar, "Mengintegrasikan HAM dan Internet", Kompas, 21 Agustus 2014. 
Peraturan Perundang - undangan

Deklarasi Universal Hak Asasi Manusia 1948

Kovenan Internasional tentang Hak Sipil Dan Politik 1966.

Undang - Undang Dasar Negara Republik Indonesia Tahun 1945

Undang - Undang Nomor 39 Tahun 1999 tentang Hak Asasi Manusia

Undang - Undang Nomor 12 Tahun 2005 tentang Pengesahan International Covenant On Civil And Political Rights (Kovenan Internasional Tentang Hak Sipil Dan Politik

Undang - Undang Nomor 9 tahun 1998 Tentang Kemerdekaan Menyampaikan Pendapat di Muka Umum

Undang - Undang Nomor 11 Tahun 2008 Tentang Informasi Dan Transaksi Elektronik

Undang - Undang Nomor 19 Tahun 2016 Tentang Perubahan Atas Undang - Undang Nomor 11 Tahun 2008 Tentang Informasi Dan Transaksi Elektronik Kitab Undang - Undang Hukum Pidana dan Kitab Undang Undang Hukum Acara Pidana (KUHP dan KUHAP)

\section{Internet}

https://id.m.wikipedia.org/wiki/gagas

an

www.elib.unikom.ac.id/files/disk1

http://www.hukumonline.com/berita/

baca/lt5057d8e58f799/akhirnya-

-ma-bebaskan-prita-mulyasari

https://news.detik.com/berita/358778

8/komika-acho-tersandung- kasus-gara-gara-curhat-soal-

apartemen

https://www.cnnindonesia.com/nasio nal/20170806143342-12-

232782/kronologi-kasus-

komika-acho-versus-apartemengreen-pramukal

http://www.academia.edu

http://www.kontras.org

https://elsam.or.id

https://kompas.com

https://mediaindonesia.com

https://dailysocial.id 